\title{
La mujer. Paciente en la unidad de hemodiálisis, cuidadora principal en casa
}

\section{Ma José Marqués Racionero, M $^{\mathrm{a}}$ Luisa Molina Conde, Virginia A. Marín Fábrega, Macarena Peña Ortega}

\section{Club de Hemodiálisis Nefrolinares. Linares. Jaén}

\section{Introducción:}

Según la bibliografía revisada se pone de manifiesto el claro predominio de las mujeres como cuidadoras informales en nuestro medio. La mayoría de las cuidadoras comparte una serie de características como menor nivel académico, sin trabajo fuera de casa y baja clase social. En la mayor parte de ellas el rol de cuidadora crea un impacto negativo sobre su salud.

\section{Material y método:}

\section{Estudio descriptivo tranversal.}

Encuesta confeccionada en base al objetivo de nuestro estudio y a la bibliografía revisada que consta de 16 ítems que contienen tanto preguntas abiertas como cerradas.

\section{Objetivos:}

Analizar la distribución del rol de cuidador entre hombres y mujeres de nuestra unidad de HD en un centro periférico. Determinar cuál es la percepción de ser cuidadora principal en las mujeres de nuestra unidad.

\section{Encuesta:}

Cada paciente, con la ayuda del personal de enfermería, durante la sesión de hemodiálisis (HD), rellena el cuestionario elaborado.

\begin{tabular}{|c|c|}
\hline \multicolumn{2}{|l|}{ Su edad es } \\
\hline Su nivel académico es & \\
\hline Su estado civil es & \\
\hline Trabaja fuera de casa & $\square$ Sí $\square$ No \\
\hline $\begin{array}{l}\text { Tiempo que lleva incluido/a } \\
\text { en programa de HD }\end{array}$ & \\
\hline $\begin{array}{l}\text { Describa el número de miem- } \\
\text { bros que convivan con usted } \\
\text { en casa y su parentesco }\end{array}$ & \\
\hline $\begin{array}{l}\text { Los días que no acude a se- } \\
\text { siones de HD dispone de } \\
\text { tiempo para usted }\end{array}$ & $\square$ Sí \\
\hline $\begin{array}{l}\text { Cuida usted a personas de su } \\
\text { hogar }\end{array}$ & $\square$ Sí \\
\hline $\begin{array}{l}\text { Cuál es el tipo de vínculo que } \\
\text { le une a las personas a las } \\
\text { que cuida }\end{array}$ & \\
\hline $\begin{array}{l}\text { Qué patologías o dependen- } \\
\text { cias tienen las personas a las } \\
\text { que usted cuida }\end{array}$ & \\
\hline $\begin{array}{l}\text { Qué tareas hace usted en } \\
\text { casa como cuidador/a de las } \\
\text { personas de su hogar }\end{array}$ & \\
\hline $\begin{array}{l}\text { Qué ayuda tiene de otras per- } \\
\text { sonas o de instituciones para } \\
\text { ejercer su rol de cuidador/a }\end{array}$ & \\
\hline $\begin{array}{l}\text { Piensa que el ser cuidador/a } \\
\text { de los suyos le repercute } \\
\text { Bien o Mal en su salud }\end{array}$ & \\
\hline $\begin{array}{l}\text { Está usted satisfecho de su } \\
\text { rol de cuidador/a }\end{array}$ & $\square$ Sí \\
\hline $\begin{array}{l}\text { Por las personas de su entor- } \\
\text { no usted se siente }\end{array}$ & $\begin{array}{c}\square \text { Cuidado } \square \text { Valorado } \\
\square \text { Necesitado }\end{array}$ \\
\hline $\begin{array}{l}\text { Escriba el parentesco que } \\
\text { usted tenga con su cuidador/a }\end{array}$ & \\
\hline
\end{tabular}




\section{Conclusiones:}

Dentro de la población de nuestro estudio las mujeres destacan mayoritariamente como cuidadoras principales en su entorno familiar. Dentro del grupo de mujeres que no pertenecen a las cuidadoras principales, parte de ellas son atendidas a su vez por mujeres, habitualmente las hijas. Hay un mayor número de mujeres que viven solas, sin cuidador/a y sin personas a su cargo, frente a una minoría de hombres.

Anexo 1.Valores porcentuales de los resultados.
Palabras clave: Cuidador principal, Calidad de vida, Hemodiálisis.

\section{Referencias Bibliográficas}

1. García Calvente MM, Mateo Rodríguez I, Maroto Navarro G. El impacto de cuidar en la salud y la calidad de vida de las mujeres. Escuela Andaluza de Salud Pública. 13 enero 2004.

2. La Parra D. Contribución de las mujeres y los hogares más pobres a la producción de cuidados de salud informales. Gac. Sanit. 2001;15:498-505.

3. Moreno Arroyo C. et al. Características del cuidado familiar a pacientes dependientes en programa de hemodiálisis. Rev. Soc. Esp. Enferm. Nefrol. V.14n.1 Madrid ene-mar. 2011.

4. García Calvente MM. Cuidados de salud, género y desigualdad. Comunidad 2002; 5:3-4. 